\title{
Mutations of androgen receptor gene in Brazilian patients with male pseudohermaphroditism
}

\author{
D.F. Cabral ${ }^{1}$, \\ A.T. Maciel-Guerra ${ }^{2}$ \\ and C. Hackel ${ }^{1,2}$
}

\author{
${ }^{1}$ Centro de Biologia Molecular e Engenharia Genética and \\ 2Departamento de Genética Médica, Faculdade de Ciências Médicas, \\ Universidade Estadual de Campinas, Campinas, SP, Brasil
}

\section{Correspondence \\ C. Hackel \\ Centro de Biologia Molecular e \\ Engenharia Genética, UNICAMP \\ Caixa Postal 6109 \\ 13083-970 Campinas, SP \\ Brasil \\ Fax: 55 (019) 788-1089 \\ E-mail: hackel_c@turing.unicamp.br \\ Research supported by FAPESP (No. 1996/3190-8) and FAEP-UNICAMP. \\ D.F. Cabral was the recipient of \\ a CNPq fellowship.}

Received October 22, 1997 Accepted March 18, 1998

\section{Abstract}

We describe the identification of point mutations in the androgen receptor gene in five Brazilian patients with female assignment and behavior. The eight exons of the gene were amplified by the polymerase chain reaction (PCR) and analyzed for single-strand conformation polymorphism (SSCP) to detect the mutations. Direct sequencing of the mutant $\mathrm{PCR}$ products demonstrated single transitions in three of these cases: $\mathrm{G} \rightarrow \mathrm{A}$ in case 1, within exon $\mathrm{C}$, changing codon 615 from Arg to His; $\mathrm{G} \rightarrow \mathrm{A}$ in case 2, within exon $\mathrm{E}$, changing codon 752 from Arg to Gln, and $\mathrm{C} \rightarrow \mathrm{T}$ in case 3 , within exon $\mathrm{B}$, but without amino acid change.

Male pseudohermaphroditism is characterized by deficiency or absence of virilization in genetically male individuals $(46, \mathrm{XY})$ with intra-abdominal or inguinal testes (1). The androgen insensitivity syndromes (AIS) are $\mathrm{X}$-linked disorders which result from defects in the androgen receptor (AR) and are the most frequent cause of male pseudohermaphroditism. Phenotypic expression of AIS is quite variable: the complete form is characterized by a female phenotype while partial forms may be found in undermasculinized males or in normal males with infertility (2).

The AR is a member of the steroid hormone receptor superfamily of ligand-dependent transcription factors, and its protein comprises 919 amino acids. The androgen receptor gene is localized in the Xq11-12 region, spanning $90 \mathrm{~kb}$ and its approximately 2757 bp coding region is organized in 8 exons.
Key words

- Androgen receptor gene

- Gene mutations

- Androgen insensitivity syndromes

- Male pseudohermaphroditism
The complete cDNA sequence consists of $3.6 \mathrm{~kb}$. The AR protein is divided into three distinct functional domains: the N-terminal domain (exon $\mathrm{A}$ ), that has a role in transcriptional activation, the central domain (exons $\mathrm{B}$ and $\mathrm{C}$ ), which consists of two zinc-finger elements responsible for DNA binding, and the $\mathrm{C}$-terminal domain (exons $\mathrm{D}$ through $\mathrm{H}$ ), responsible for androgen binding (3).

The heterogeneity in the phenotypic expression of AIS is due to a variety of androgen gene mutations which include deletions and point mutations, with the latter causing amino acid substitutions, premature termination of transcription and inappropriate splicing of RNA (4).

In the present study we report the results of molecular analysis of the androgen receptor gene in five unrelated subjects with a clinical diagnosis of complete androgen in- 
Table 1 - Age at diagnosis and familial recurrence status of the five CAIS patients.

${ }^{*}$ One of the two maternal aunts of subject 5 was previously examined by us.

\begin{tabular}{ccc}
\hline Subject & Age (years) & Familial recurrence \\
\hline 1 & 26 & sister and maternal aunt \\
2 & 16 & none \\
3 & 21 & sister and maternal aunt \\
4 & 14 & none \\
5 & 2 & two maternal aunts $\left(^{*}\right)$
\end{tabular}

sensitivity syndrome (CAIS). The five patients (Table 1) presented normal female external genitalia but a male karyotype $(46, X Y)$. Physical and hormonal features were consistent with CAIS and the gonads were testes.

Genomic DNA was isolated from patient leukocytes by standard methods. The eight exons of the gene were amplified by the polymerase chain reaction (PCR) and screened for single-strand conformation polymorphism (SSCP) to identify mutations. PCR was performed using 11 sets of primers $(5,6)$. The exon A coding sequence was subdivided into four overlapping fragments due to its large size (1613 bp).

Since SSCP is more sensitive for fragments of less than $350 \mathrm{bp}$, the PCR products of the three fragments from exon A and from exon D were cleaved with appropriate restriction enzymes prior to electrophoresis. The denatured PCR products were run on non-denaturing 12.5 and $20 \%$ polyacrylamide Phastgel in the absence of glycerol using the Pharmacia PhastSystem (Uppsala, Sweden). Electrophoresis was carried out at either 15 or $20^{\circ} \mathrm{C}$ for $2 \mathrm{~h}$ at $150 \mathrm{~V}$, and the gels were silver-stained.

Band-shifts in SSCP gels were detected in three cases, on exons B, C and E. Direct sequencing was performed with PCR products from two separate reactions using the sense and antisense primers labelled with $\gamma$ $\mathrm{P}^{32}$-ATP and the Thermosequenase kit (Amersham Life Science Inc., Cleveland,
$\mathrm{OH})$. The sequencing of the putative mutant segments revealed $\mathrm{G} \rightarrow \mathrm{A}$ transitions in two instances: at position 2348 (exon C) in case 1 , resulting in the Arg615His substitution (Figure 1A), and at position 3136 (exon E) in case 2, resulting in the Arg752Gln substitution (Figure 1B). In case 3, a cytosine to thymine mutation at nucleotide 1989 (exon B) was found, but this substitution did not result in amino acid changes (Ala585Ala).

We have encountered some difficulties in the amplification and SSCP analysis of exon $\mathrm{A}$, since these regions contain a highly polymorphic polyglutamine (CAG) stretch and a highly GC-rich segment encoding a polyglycine stretch. Two polymorphisms were studied in this exon: the number of CAG repeats and the $S t u I$ restriction enzyme polymorphism $(7,8)$. The number of CAG repeats varied from 18 to 24 , being within the normal range (9). The analysis of StuI polymorphism showed that all patients were positive for this restriction enzyme site, which is the most frequent allele in American Caucasian males (8).

To date, 245 mutations were described in the androgen receptor gene that give rise to AIS. A regular data base has been compiled and updated by Gottlieb et al. (10) and is available from EMBL (http://www.mcgill.ca/ androgendb).

Most of the mutations identified in the AR gene are different, with very few patients sharing the same mutation. The same mutation can be associated with different phenotypes not only from different families but even within the same family. The distribution of androgen receptor gene mutations is interesting also for the clustering of mutations in specific areas of the receptor protein in or around exons $E$ and $G$, as well as for the paucity of mutations that have been localized on exon A. Only mutations in exons B and $\mathrm{C}$ have an expected phenotype, which is almost always related to CAIS (11).

The Arg615His substitution (case 1) has already been described in CAIS patients (12- 


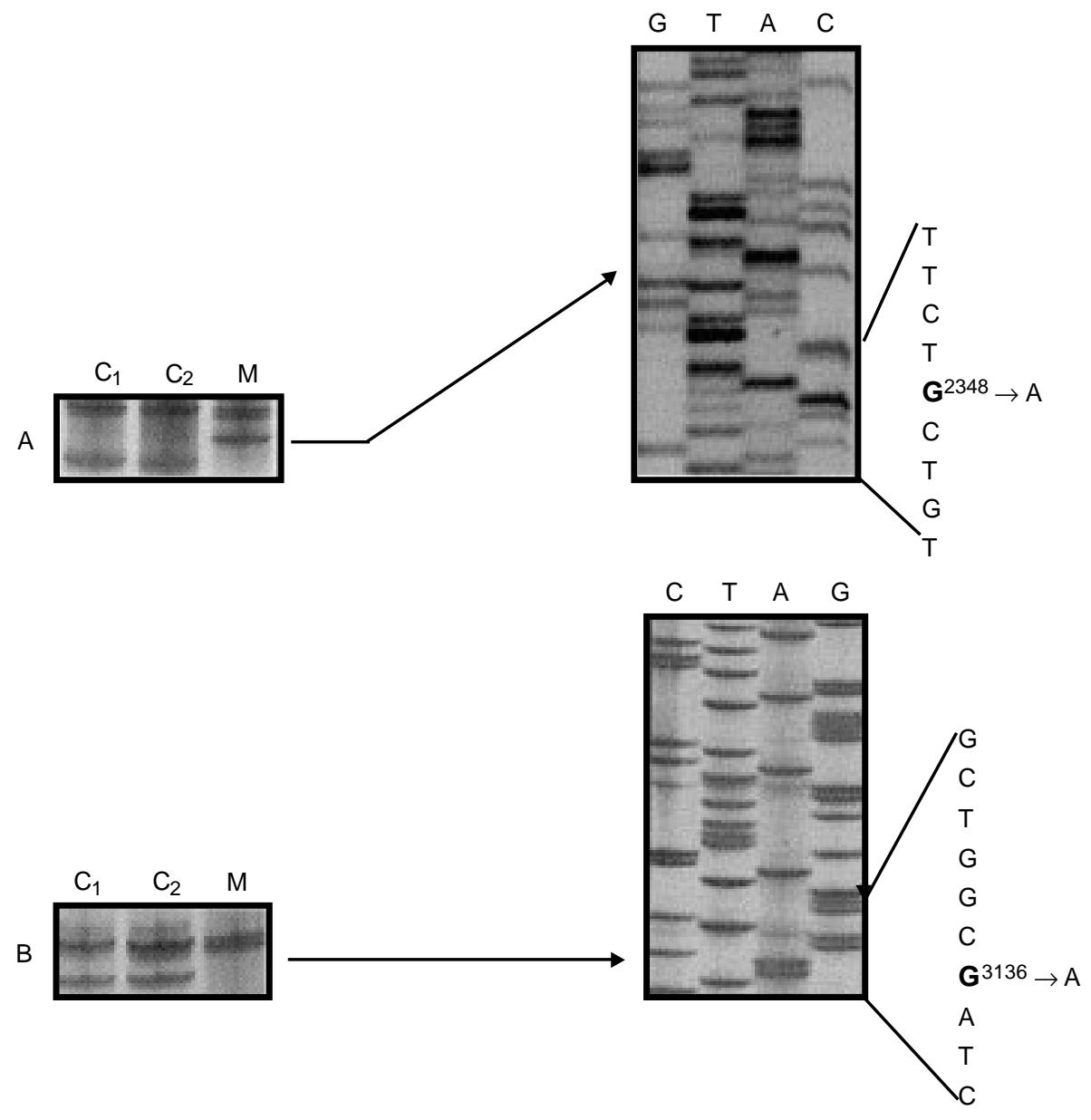

15). This mutation prevents the androgen receptor from binding the androgen responsive element (ARE) consensus and abolishes its transactivational competence in vitro, being probably sufficient to cause complete AIS (13).

The Arg752Gln substitution (case 2) has also been detected in patients from two families (16,17). Evans (16) reported the absence of hormone-receptor binding on genital skin fibroblasts from one of these patients. According to this author, this mutation is identical and functionally equivalent to that observed at amino acid 734 of the rat androgen receptor in rat testicular feminization. Mutations in exon E represent about $40 \%$ of all molecular alterations involving amino acid changes described in the hormone-binding domain (3).
Since the detection rate for SSCP is estimated to be 70 to $80 \%$ (6), exons $\mathrm{B}$ to $\mathrm{H}$ from cases 3, 4 and 5 were completely sequenced to exclude the existence of mutations in these regions, and none were found. However, undetected mutations may still exist in exon A, not sequenced in this study, or may be related to the androgen receptor gene promoter (18). Somatic mosaicism may also be postulated since genomic DNA was isolated from leukocytes, and not from tissues where the AR gene is expressed, like genital skin (19).

There is still the possibility that some mutations were missed by the screening procedure, although some cases may be the result of other, as yet undefined, genetic lesions (20).
Figure 1 - Non-isotopic SSCP (left) and sequencing analysis (right) of patients $1(A)$ and 2 (B). The sequence numbering adopted was that established by Lubahn et al. (5). C, Control; M, mutant. 


\section{References}

1. Griffin JE (1992). Androgen resistance the clinical and molecular spectrum. New England Journal of Medicine, 326: 611618.

2. MacLean HE, Warne GL \& Zajac JD (1995). Defects of androgen receptor function: from sex reversal to motor neurone disease. Molecular and Cellular Endocrinology, 122: 133-141.

3. Quigley CA, DeBellis A, Marschke KB, EIAwady MK, Wilson EM \& French FS (1995). Androgen receptor defects: historical, clinical, and molecular perspectives. Endocrinology Reviews, 16: 271321.

4. Pinsky L, Beitel LK, Kazemi-Esfarjani P, Lumbroso R, Marie Vasiliou D, Shkolny D, Abdullah AAR, Gottlieb B \& Trifiro MA (1996). Lessons from androgen receptor gene mutations that cause androgen resistance in humans. Frontiers of Endocrinology, 20: 95-114.

5. Lubahn DB, Brown TR, Simental JA, Higgs HN, Migeon CJ, Wilson EM \& French FS (1989). Sequence of the intronexon junction of the coding region of the human androgen receptor gene and identification of a point mutation in a family with complete androgen insensitivity. Proceedings of the National Academy of Sciences, USA, 86: 9534-9538.

6. Batch JA, Evans BAJ, Hughes IA \& Patterson MN (1993). Mutations of the androgen receptor identified in perineal hypospadias. Journal of Medical Genetics, 30: 198-201.

7. Yee CJ, Roodi N, Verrier CS \& Parl FF (1994). Microsatellite instability and loss of heterozygosity in breast cancer. Cancer Research, 54: 1641-1644.

8. Lu J \& Danielsen M (1996). A Stul polymorphism in the human androgen recep- tor gene (AR). Clinical Genetics, 49: 323324.

9. Edwards A, Hammond HA, Jin L, Caskey T \& Chakraborty R (1992). Genetic variation at five trimeric and tetrameric tandem repeat loci in four human population groups. Genomics, 12: 241-253.

10. Gottlieb B, Trifiro M, Lumbroso R, Vasiliou DM \& Pinsky L (1997). The androgen receptor gene mutations database. Nucleic Acids Research, 25: 158-162.

11. McPhaul MJ, Marcelli M, Zoppi S, Griffin JE \& Wilson JD (1993). Genetic basis of endocrine disease 4 - The spectrum of mutations in the androgen receptor gene that causes androgen resistance. Journal of Clinical and Endocrinological Metabolism, 76: 17-23.

12. Brown TR, Scherer PA, Chang $Y T$, Migeon CJ, Ghirri P, Murono K \& Zhou Z (1993). Molecular genetics of human androgen insensitivity. European Journal of Pediatrics, 152 (Suppl 2): S62-S69.

13. Beitel LK, Prior L, Vasiliou DM, Gottlieb B, Kaufman M, Lumbroso R, Alvarado C, McGillivray B, Trifiro M \& Pinsky L (1994). Complete androgen insensitivity due to mutations in the probable alpha-helical segments of the DNA-binding domain in the human androgen receptor. Human Molecular Genetics, 3: 21-27.

14. Ris-Stalpers C, Hoogenboezem T, Sleddens HFBM, Verleun-Mooijman MCT, Degenhart HJ, Drop SLS, Halley DJJ, Oosterwijk JC, Hodgins MB, Trapman J \& Brinkmann AO (1994). A practical approach to the detection of androgen receptor gene mutations and pedigree analysis in families with X-linked androgen insensitivity. Pediatrics Research, 36: 227-234.

15. Hiort O, Sinnecker GHG, Holterhus P-M,
Nitsche EM \& Kruse K (1996). The clinical and molecular spectrum of androgen insensitivity syndromes. American Journal of Medical Genetics, 63: 218-222.

16. Evans BAJ (1992). Detection of a point mutation within the androgen receptor gene in a family with complete androgen insensitivity syndrome and subsequent prenatal diagnosis. Journal of Endocrinology, 135: 26 (Abstract).

17. Brown TR, Newmark J \& Ghirri P (1992). Six naturally occurring mutations in the 144-base pairs of exon $E$ of the human androgen receptor gene. Program of the 74th Annual Meeting of the Endocrine Society, 1992, San Antonio, TX, 428 (Abstract 1506).

18. Rodien P, Mebarki F, Mowszowicz I, Chaussain J-L, Young J, Morel Y \& Schaison G (1996). Different phenotypes in a family with androgen insensitivity caused by the same M780I point mutation in the androgen receptor gene. Journal of Clinical and Endocrinological Metabolism, 81: 2994-2998.

19. Bohemer ALM, Brinkmann AO, Niermeijer MF, Bakker L, Halley DJJ \& Drop SLS (1997). Germ-Line and somatic mosaicism in the androgen insensitivity syndrome: implications for genetic counseling. American Journal of Human Genetics, 60: 1006-1007.

20. Mebarki F, Forest MG, Josso N, Bertrand AM, David M, Chatelain P \& Morel $Y$ (1994). Complete direct sequencing of the entire AR gene in 45 unrelated patients with androgen insensitivity syndrome: mutations identified in 32 patients (18 novel mutations), no mutation detected in 13 other patients (29\%). American Journal of Human Genetics, 55: 231 (Abstract 1348). 